\title{
Impact Of Retirement Benefit Act (RBA) On Investment Returns To Pension Funds In Kenya
}

Lucy Jepchoge Rono, Moi University, Kenya

Julius Kibet Bitok, Moi University, Kenya

Gordon N Asamoah, Kwame Nkrumah University, Ghana

\begin{abstract}
This study focused on the analysis of the impact of RBA guidelines on the return on investments of both pension funds under management and those for pension schemes. A random sample of 175 fund trustees and a census of 13 fund managers from registered fund management companies participated in the survey. The questionnaire was administered through the drop-and-pick method. Data were analyzed using SPSS (Statistical Package for Social Sciences) and summarized in descriptive statistics, such as mean, standard deviation, frequencies, percentages, and t-tests for mean differences were used. The study determined that annual investment return for retirement benefits schemes in the past three years ranged between 10 and $27.52 \%$, sometimes falling below the annual inflation. The Kenya pension funds are in compliance with the prescribed broad guidelines with regard to maximum percentages of total asset value of fund by the RBA Act. They are, however, moderately in compliance with the regulations requiring that that they maintain an actuarial solvency of $80 \%$ and above. The overall weighted returns before the implementation of RBA Guidelines was low (average scale of 1.9) while the weighted returns after the implementation of RBA Guidelines was high, at an average scale of 3.7. An analysis of the trend, however, showed that long-run performance has slowed down. The highest growth was realized for mortgage and cash returns as opposed to rights issues and bonus shares. There is need to fashion out the appropriate mix of reforms suitable for Kenya that will ensure the long-run sustainability of its pension systems. The challenge is for the country to adopt a unified, harmonized, and transparent regulatory framework that will integrate the pension system in order to ensure sustainability in its financing and mobilizing of adequate funds to cater for the ever-increasing population of beneficiaries in this regard, comprehensive pension reform policy with wider target radar and one that will consolidate and harmonize the various legislations touching on retirement benefits industry in line with Retirement Benefits Act. The Regulator needs to implement measures to ensure pension funds are insulated from inflationary and other risks. An effective way is to institute a pension risk insurance fund that will underwrite and compensate such losses as will be prescribed. Further, there is need for a systematic indexation of benefits to inflation. RBA should strengthen its compliance and enforcement function in order to ensure that it appropriately deals with emerging present and future regulatory challenges.
\end{abstract}

Keywords: pension funds, investment, returns, Retirement Benefits Act

\section{INTRODUCTION}

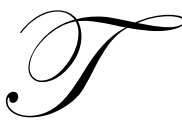

he need for better and more specific measures to protect the interests of employees in pension plans had become apparent in Kenya by about 1991.Employers had unlimited access to the pension funds and would use it to improve their cash flows in the company. Some of the cases include Railway Corporation, National Society Security Fund, Postal Corporation and the University of Nairobi (Otieno, 2003) This problem was as a result of a bad investment profile characterized by lack of diversity, a pension fund such as that of 
National Society Security Fund with an overwhelming $72 \%$ of total assets was in real estate. Additionally, $7 \%$ of the fund was invested in bank deposits with 16 financial banking institutions of which 10 have collapsed, thus leading up to $4.6 \%$ of the total fund assets (Odundo, 2003). Also, trustees were the top managers of the employer and others were political appointees who misused employer contributions, which resulted in cases of poor pension investments, delays and denials in payments of dues to members, misuse and outright embezzlement of the scheme funds by the same trustees who were entrusted to guard the funds to the ultimate loss to the beneficiaries (Moridnat, 2005).

The Retirement Benefits Act was set up by the ministry of finance in 1997 with the following objectives: 1) to regulate \& supervise the management of their retirement benefits schemes, 2) to protect interest of members and sponsors of their retirement benefits, 3) to promote the development of the retirement benefits sector, 4) to advise the Minister on the national policy and to implement government policies, and 5) to perform such other functions as are conferred by the Act (Kiptanui, 2003).

\section{Statement of the Problem}

Since the inception of RBA, a number of pension schemes have either restructured their investment portfolio or re-assessed their investment returns to be compliant with the Act. Many have complained that the RBA is too restrictive to the detriment of the members. It required the pension scheme to meet various mandatory requirements, which consume a lot of funds (Mworia 2000). However, the stakeholders including trade unions and other bodies, applause the government for their initiative, arguing that pension schemes in Kenya lacked investment guidelines to enable them to attain maximum results (Odundo 2003). It is evident that Returnees at Railway Corporation, University of Nairobi and National Social Security Fund were either unable to pay or paid less than the minimum portfolio return in Kenyan Market (Otieno 2003). A study conducted by World Bank (WB2007) indicates that Kenya workers are condemned to old age poverty due to lack of clear acts to regulate investment of pension funds. The recent survey shows that since the implementation of RBA, professional management of pension schemes, investment and returns are given priority. The current study therefore traces the impact of RBA on pension investment returns.

\section{Objective of the Study}

The main objective of this study was to critically establish the impact of Retirement Benefits Act (RBA) on pension fund investment returns. The specific objective was to compare the level of pension investment returns before and after the implementation of the RBA Act.

\section{LITERATURE REVIEW}

\section{The Concept of Pension}

Prieto describes a pension fund as the set of payment promises in favour of the plan that are protected by property rights, (Prieto 2002). For the purpose of this study, pension is defined as sum of money paid regularly by the state or by trustees to an employee upon normal or ill- health retirement. (Dearborn, 1999) Although Pearbou (1999) has exhaustively described the meaning and origin of pension and its purpose, he failed to describe how the investment returns are affected by various regulations governing the pension funds. This study therefore traces the sources of the pension funds, how they are invested and legislation, which affect their returns. Various studies were reviewed in line with investment of pension schemes. It is important to note that the studies are mainly foreign with a few local ones .In a study by Mghali (2003) concluded that firms should conduct pension schemes where the employer contributes a certain percentage together with the employee contribution and then invested and trustees should control the fund. Mugweru (2001) in his study on National Social Security Fund (NSSF) recommended that investment department at NSSF should consist of professionals who adhere to proper investment policies and procedures. 


\section{Pension Reforms}

Pension reforms have taken place in various countries worldwide. Each country has handled reform on investment differently but all have similar underlying principles on diversification and a balance of risk and return trade off to achieve optimum return.

In New Zealand the legislations sets restrictions on when, and at what rate the government can draw the fund and the use needs to be published Ireland directly restricts the pensions revenue toward misuse of the public pensions fund for the government own purposes by explicitly prohibiting investment by the fund (Holzmann and Hinz, 2005) Irish government securities. Hotzmann and Hunz (2005) describe the legislation of Irish Republic governing pension funds but failed to acknowledge that the legislation governing developed countries may not fit precisely with the conditions prevailing in developing countries. The research therefore will give special emphasis on the developing countries.

Morocco Public Pension Fund managers have a reasonable institutional capacity. The funds are managed through an internal investment unit; the unit has three committees, an investment committee, the placement committee and supervisory committee (Robalino, 2005). Robalino (2005) has introduced the Scenario of pension acts in Morocco without elaborating how they have impacted on the returns of the investment. Kenya has introduced the use of investment guidelines as discussed in detail in section

\section{Retirement Benefits Act}

The RBA Act was enacted in 1997 with five major objectives. Firstly to Regulate \& supervise the management of retirement benefit schemes. Secondly, to protect interest of members and sponsors of retirement benefit. Thirdly promote the development of the retirement benefit sector, fourthly to advise the Minister on the national policy and to implement Government policies and fifthly to perform such other functions as are conferred by the Act (Kiptanui, 2003)

The RBA implementation provides specific details on mandatory for pension schemes sections of the Act to be complied with five years after commencement. This included, Section 16-The Retirement Benefits Levy, Section 24-Registration of Schemes, Section 34-Annual Report \& Accounts and Section 37-Prudent Investment policy (Mworia, 2000) Section 37 of the Act is the focus of this study. This part of the Act requires trustees to ensure the scheme has a prudent investment policy on the investment of its funds so as to maintain the capital of the scheme and secure market rates of returns on its investment. The investment policy of a scheme must be implemented and reviewed every three years in consultation with RBA (Machira, 2004).

\section{Conceptual Framework}

The study will adopt a conceptual framework taking the RBA guidelines as the independent variable and the level of the investment returns to members as the dependable variable. The RBA guidelines, centre around five objectives which include to supervise the establishment and management of pension schemes, protecting the interests of members and sponsors, promoting the development of the pension sector, advising the minister for finance on the national policy and implement all government policies relating to pension schemes. The dependent variable incorporates the aspects of relations in terms of liquid case, dividends, interests, and shares in companies and mortgage loans. The interviewing variable will be the managerial aspects and functions, which are supposed to direct and redirect members' contribution into viable investments. The management leaders will utilize the investment appraisal techniques to effectively attain the objectives. The diagram below illustrates this. 
Figure 1: Effects of RBA Guidelines on Pension Scheme Returns to Members

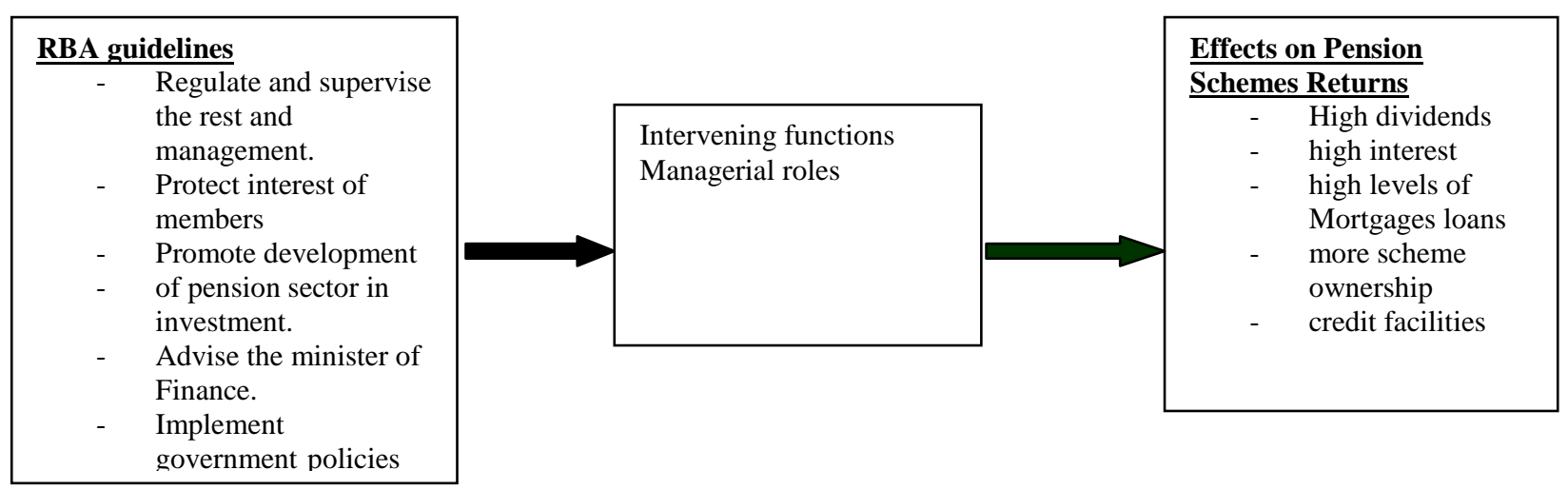

From the above diagram if the pension scheme comply with RBA guidelines and the appointed managers with the assistance of investment appraisal methods such as Net present value, accurate rate of returns, cost benefit analysis, rest analysis portfolios and the break even analysis. The final result will yield to high returns inform of high share dividends, interests on debentures and bank loans, more shares in companies which are quoted in Stock Exchange and high Mortgage to our own homes.

\section{RESEARCH METHODOLOGY}

\section{Research Design}

The study used a cross sectional survey design. This design has been used by World Bank in follow up assessments of pension reforms in foreign countries such as Sweden, Ontario Canada, (Mikula, 2000). A survey research attempts to collect data from members of a population and describes existing phenomena by asking individuals about their perception, attitudes behavior or values. Moreover, it explores the existing status of two or more variables at a given point in time. Primary data collected from such a population is more reliable and up-todate (Mugenda \& Mugenda, 1999).

\section{Target Population}

The target population, which the research covered, consisted of two categories. One group consisted of all the 13 fund managers registered with the Retirement Benefit Authority RBA. The fund managers provided insight information on level of compliance to the RBA investment guidelines and its effect on return on investment since its implementation.

The second category of respondents consisted of trust secretaries of 1,753 pension schemes registered with the Retirement Benefits Authority.

\section{Sample Size and Sampling Techniques}

For the first category of respondents, a census study was adopted as all the fund managers were targeted for the study. The 1,753 registered pension schemes constituted the sampling frame for the second category of respondents for the study. Random sampling will be used to select 20\%, which is equal to 350 registered pension schemes. The trust secretaries of the sampled registered pension schemes were the respondents.

The study used two sets of simple structured questionnaires which were administered to the two categories of respondents through post office mailing and follow up by physical drop and pick by research assistants to pension schemes located within a radius of $50 \mathrm{~km}$ from Nairobi Central Business District. Each questionnaire was 
accompanied by an introduction letter from Moi University School of Business and Management indicating the area of research to be undertaken by the researcher and confirming that the research information will be treated confidentially and is for academic purposes. The instrument contained closed and open-ended questions. The questionnaire captured ways of operations, management style, level of expertise, resource availability such as technology, which enables the fund manager to comply with the RBA investment guidelines and track down pension investment returns in form of interest on monthly, quarterly, half yearly or annually.

\section{DATA ANALYSIS AND RESULTS}

A content analysis of the responses to open-ended questions has been presented as qualitative data for a better understanding of the researched themes.

\section{QUANTATIVE ANALYSIS}

\section{Demographics for Mangers of Registered Pension Schemes}

In this section, respondents' characteristics are analyzed. Respondents were asked to indicate their gender, age, highest level of education, professional background, experience in pension fund management, position, and the recruitment mode. The results are presented in Table 1.

Table 1: Characteristics of the Managers of Registered Pension Funds

\begin{tabular}{|c|c|c|c|}
\hline Variable & Measurement scale & Number of employees & Percentage \\
\hline \multirow{2}{*}{ Gender } & Male & 108 & 81.8 \\
\hline & Female & 24 & 18.2 \\
\hline \multirow[t]{4}{*}{ Age } & $0-30$ & 36 & 27.3 \\
\hline & $31-40$ & 39 & 29.5 \\
\hline & $41-50$ & 27 & 20.5 \\
\hline & Above 50 & 30 & 22.7 \\
\hline \multirow[t]{4}{*}{ Highest level of education } & Secondary & 3 & 2.3 \\
\hline & Tertiary & 36 & 27.9 \\
\hline & University & 57 & 44.2 \\
\hline & Post University & 33 & 25.6 \\
\hline \multirow[t]{7}{*}{ Profession } & Accountancy & 46 & 29.3 \\
\hline & Administration & 21 & 13.4 \\
\hline & Marketing & 13 & 8.3 \\
\hline & Public relation & 8 & 5.1 \\
\hline & Economics & 61 & 38.9 \\
\hline & Actuarial Science & 3 & 1.9 \\
\hline & IT & 5 & 3.1 \\
\hline \multicolumn{4}{|c|}{ Experience in the pension scheme } \\
\hline & $0-10$ & 119 & 82.6 \\
\hline & $11-20$ & 15 & 10.4 \\
\hline & $21-30$ & 7 & 4.9 \\
\hline & Over 30 & 3 & 2.1 \\
\hline \multicolumn{4}{|c|}{ Position in the pension scheme } \\
\hline \multirow[t]{3}{*}{ Mode of recruitment } & election & 81 & 71.1 \\
\hline & appointment & 30 & 26.3 \\
\hline & secondment & 3 & 2.6 \\
\hline
\end{tabular}

Majority of the managers of registered pension schemes interviewed are males (81. 8\%) aged above 30 years with post tertiary education in accountancy and economics. In addition, they play the role of asset management trustees in the pension schemes and have been working with the current pension schemes for less than 10 years. Majority $(71.1 \%)$ were recruited through election. 


\section{Demographics for Registered Pension Schemes}

This section presents fund mangers' attributes. The respondents were asked to indicate their educational and their experience in pension fund management. The results are presented in Table 2

Table 2: Fund Managers' Attributes

\begin{tabular}{lccc}
\hline Variable & Measurement scale & Number of employees & Percentage \\
Educational background & Tertiary & 1 & 10 \\
& University & 3 & 30 \\
Experience in pension fund management & Post University & 6 & 60 \\
& $0-10$ & 3 & 30 \\
& $11-20$ & 5 & 50 \\
& $21-30$ & 1 & 10 \\
\hline
\end{tabular}

Majority of the fund managers interviewed have post tertiary education and have experience in pension fund management spanning 20 years and below.

Table 3 is a summary of the current market share of the pension fund managers in the country. As shown, AIG Global Investment Company (EA) and Old Mutual Asset Managers are the market leaders, commanding an estimated $22.9 \%$ and $22.5 \%$ of the total investment portfolios respectively. Genesis Kenya Investment Services (13.8\%), ICEA Investment Services (9.6\%) and Co-op Trust Investment Management (9.2\%) follow in that order. In terms of the numbers of pension schemes being managed, ICEA Investment Services takes the lead (33.8\%), followed by Old Mutual Asset Managers Kenya (11.1\%), Jubilee (10.8\%), Kenindia (10.6\%) and Co-op Trust Investment Management (9.2\%). There is an inverse relationship in the number of pension schemes under management and the value asset portfolio with the two market leaders in asset portfolio value having relatively less pension schemes under management. This implies that the market leaders are more likely to offer higher net benefits to the pension schemes under management as a result of accrued benefits resulting from economies of scale compared to those with many but small value portfolio pension schemes.

Table 3: Fund Mangers' Market Share

\begin{tabular}{|l|c|c|c|c|}
\hline \multicolumn{1}{|c|}{ Fund manager market share } & Total investment Portfolio & \% of total & no of schemes & \% of total \\
\hline ICEA Investment Services & 17521.03 & 9.6 & 360 & 33.8 \\
\hline Old Mutual Asset Managers (K) & 40949.59 & 22.5 & 118 & 11.1 \\
\hline Jubilee & 5189.7 & 2.8 & 115 & 10.8 \\
\hline Kenindia & 3442.46 & 1.9 & 113 & 10.6 \\
\hline Co-op Trust Investment Management & 16832.75 & 9.2 & 98 & 9.2 \\
\hline CFC Financial Services & 5363.46 & 2.9 & 67 & 6.3 \\
\hline Genesis Kenya Investment Services & 25101.57 & 13.8 & 61 & 5.7 \\
\hline Stanbic Investment Management Service (EA) & 13136.12 & 7.2 & 55 & 5.2 \\
\hline AIG Global Investment Company (EA) & 41802.1 & 22.9 & 34 & 3.2 \\
\hline Madison Asset Management Services & 6655.13 & 0.4 & 29 & 2.7 \\
\hline Old Mutual Asset Managers (K) & 11845.19 & 6.5 & 5 & 0.5 \\
\hline African Alliance (K) & 542.09 & 0.3 & 11 & 1.0 \\
\hline Total & 182391.19 & 100.0 & 1066 & 100.0 \\
\hline
\end{tabular}

Source: RBA (2008); Author's own computations

\section{Investments used by Pension Schemes in Kenya}

Respondents were asked to indicate the portfolio investments that their pension schemes investment in. As provided for Table 4, majority (71.8\%) indicated that the pension schemes invests in Kenya Government Securities 
and quoted equity (shares), an indication of risk-averseness in pension fund investments. The percentage for investment in guaranteed funds and government securities is a reflection of the shift in asset allocation patterns due to the current global crisis. Investment schemes have moved into more conservative investments. Such moves risk locking in portfolio losses and but could also reduce the potential of funds to generate retirement incomes in the future. The choice of more conservative asset allocation is also a reflection of the current restrictive and high market-based solvency rules which dictate investment strategies.

Table 4: Investment Portfolios by Pension Investment Schemes

\begin{tabular}{|l|c|c|}
\hline \multicolumn{1}{|c|}{ Investment portfolio } & Frequency & Percentage \\
\hline Government securities & 65 & 39.9 \\
\hline Shares & 52 & 31.9 \\
\hline Guaranteed fund & 18 & 11.0 \\
\hline Commercial papers & 13 & 8.0 \\
\hline Off share investment & 11 & 6.7 \\
\hline Immovable property & 3 & 1.8 \\
\hline Share in unquoted companies & 1 & 0.6 \\
\hline Total & 163 & 100 \\
\hline
\end{tabular}

Source: Survey Data (2008)

The above result is further supported by secondary data from the industry regulator (RBA). An aggregation of the investment vehicles by pension funds in Kenya is presented in Table 5. As shown, Kenya pension fund investment portfolio is highly diversified in all the vehicles except for some extent of concentration on Kenya government securities (39.5\%), quoted equity $(27.5 \%)$ and guaranteed funds $(12.3 \%)$. The concentration is a reflection of the risk-averseness of the pension fund managers. It is notable that the current global meltdown has significantly reduced the value of retirement assets especially offshore and equity investments. The Nairobi share index has trended downwards, falling to 3,521 points in December 2008 and 2,474.8 points in February 2009 after having progressively rose to stand at 5,445 in December 2007. The fall in the value of retirement assets is likely to impair the solvency of pension plan sponsors and the funding levels of defined benefit (DB) plans and also reduce the amount of money that individuals have accumulated in defined contribution (DC) pension plans.

Table 5: Fund Mangers' Investment Portfolio Diversity

\begin{tabular}{|l|c|c|}
\hline Fund Managers investment portfolio (KShs Million) & Total Portfolio & Percent (\%) \\
\hline Government securities & 72116.65 & 39.5 \\
\hline Quoted equity & 50183.52 & 27.5 \\
\hline Guaranteed funds & 22389.87 & 6.3 \\
\hline Fixed deposits & 12704.09 & 4.9 \\
\hline Offshore & 8925.7 & 4.5 \\
\hline Cash & 8283.06 & 4.0 \\
\hline Immovable property & 7326.13 & 0.2 \\
\hline Unquoted equity & 325.19 & 0.1 \\
\hline Others & 137 & 100.0 \\
\hline Total & 182391.2 & \\
\hline
\end{tabular}

Source: RBA (2008); Author's own computations

Table 6 presents the responses on the factors affecting pension fund managers' choice of investment vehicles. As shown guaranteed funds, past port folio performance and RBA guidelines rank very highly in determining fund managers choice of investment vehicles as opposed to trends in interest rates, decision making preference and risks. Past returns and investment portfolio were ranked high. 
Table 6: Factors Affecting Pension Fund Managers' Choice of Investment Vehicles

\begin{tabular}{|l|c|c|}
\hline Factors affecting choice of investment & weighted average & Level \\
\hline Guaranteed returns & 4.8 & Very high \\
\hline Past performance & 4.7 & Very high \\
\hline RBA investment guideline & 4.5 & High \\
\hline Past returns & 4.2 & High \\
\hline Investment Portfolio & 4.1 & Moderate \\
\hline Trends of interest rates & 3.2 & Moderate \\
\hline Decision making preference & 3.2 & Moderate \\
\hline Risks & 2.9 & . \\
\hline
\end{tabular}

Source: Survey Data (2008)

\section{Types of Returns that Pension Schemes and Managers Receive from Investments}

Respondents were asked to indicate the types of returns member of their pension schemes receive. Almost half $(49.1 \%)$ of the study participants indicated that members receive cash dividends. Further, $30.7 \%$ of them indicated bonus share while $8 \%$ indicated interest. Majority of the respondents indicated that the average overall annual investment return for retirement benefits schemes in the past three years has ranged between 10-27.52\%, sometimes falling below the annual inflation. This has significant implications on old age earnings and consequential poverty of retirees as the rate of returns are not inflation insulated and the pension systems currently lack systematic indexation of benefits to inflation. The results are presented in Table 7 .

Table 7: Returns that Pension Schemes Receive from Investments

\begin{tabular}{|l|c|c|}
\hline & Frequency & Percentage \\
\hline Cash dividends & 80 & 49.1 \\
\hline Script/ Bonus share & 50 & 30.7 \\
\hline Interest & 13 & 8.0 \\
\hline Rights issue & 12 & 7.4 \\
\hline Mortgage loan & 8 & 4.9 \\
\hline & 163 & 100.0 \\
\hline
\end{tabular}

Comparison of the Level of Pension Investment Returns before and after the Implementation of RBA Act

The study participants were requested to describe the level of pension investment returns before and after implementation of RBA Investment Guidelines on a 5-point likert scale ranging from very high to very low. The results are presented in Table 8 . As shown, the overall weighted returns before the implementation of RBA Guidelines was low (average scale of 1.9) while the weighted returns after the implementation of RBA Guidelines has been high, at an average scale of 3.7. Highest growth was realized for mortgage and cash returns as opposed to rights issues and bonus shares. This implies that the implementation of the RBA Guidelines enhanced the performance of the pension funds.

Table 8: Weighted Average Returns before and after the RBA Guidelines

\begin{tabular}{|l|c|c|c|c|c|}
\hline & $\begin{array}{c}\text { weighted average } \\
\text { returns- Before RBA } \\
\text { Guidelines }\end{array}$ & Level & $\begin{array}{c}\text { weighted average } \\
\text { returns- after RBA } \\
\text { Guidelines }\end{array}$ & $\begin{array}{c}\text { Growth in } \\
\text { Level } \\
\text { returns }\end{array}$ & $\begin{array}{c}\text { Hean } \\
\text { reted }\end{array}$ \\
\hline Cash returns & 1.5 & low & 3.5 & High & $\mathbf{1 3 3 . 3}$ \\
\hline Dividends & 1.7 & low & 3.3 & High & $\mathbf{9 4 . 1}$ \\
\hline Mortgage & 1.6 & low & 3.9 & High & $\mathbf{9 0 . 5}$ \\
\hline Interest & 2.1 & low & 4.0 & High & 72.7 \\
\hline Bonus share & 2.2 & low & 3.8 & High & 71.4 \\
\hline Rights issue & 2.1 & low & 3.6 & High & $\mathbf{9 4 . 7}$ \\
\hline Overall & 1.9 & Low & 3.7 & & \\
\hline
\end{tabular}


The above result is further supported by the analytical results of pension return performance trends performance trends from year 1986 to 2007. These are presented in Tables 9, 10 and Figures 2 and 3 below.

Table 9 presents the annual net average rate of weighted return for Pension funds under Management. As indicated, pension funds under management recorded negative mean rate of return $(-25.3 \%)$ before the implementation of the RBA Guidelines as compared to the positive performance of cumulative $8.1 \%$ after the implementation of the guidelines.

Table 9: Annual Net Average Rate of Weighted Return for Pension Funds under Management

\begin{tabular}{|c|c|c|c|c|c|}
\hline & & $\mathbf{N}$ & Mean & $\begin{array}{c}\text { Std. } \\
\text { Deviation }\end{array}$ & $\begin{array}{c}\text { Std. Error } \\
\text { Mean }\end{array}$ \\
\hline \multirow{2}{*}{$\begin{array}{l}\text { Annual net average rate of } \\
\text { weighted return for Pension } \\
\text { funds under Management }\end{array}$} & $\begin{array}{l}\text { before the implementation of RBA } \\
\text { guidelines }\end{array}$ & 11 & -25.3 & 19.9 & 6.0 \\
\hline & $\begin{array}{l}\text { after the implementation of RBA } \\
\text { guidelines }\end{array}$ & 11 & 8.1 & 3.5 & 1.1 \\
\hline
\end{tabular}

As can be seen from the linear trend in Figure 2, returns for pension funds under management were negative from year 1986 to year 1996 when the trend reversed and has been an upward trajectory since. It is however notable from Figures 2 and 3 that the annual net rate of returns for both funds under management and those under pension schemes has since 1998, averaged below 15\% and 5\% respectively. This is an indication of fund managers and investment trustees' continued complacence and laxity in complying with the governance mechanisms introduced by the RBA Guidelines. This is a further indication of the current inadequate capacity of the RBA to enforce its guidelines.

Figure 2: Trend of Returns for Pension Funds under Management: 1986-2007

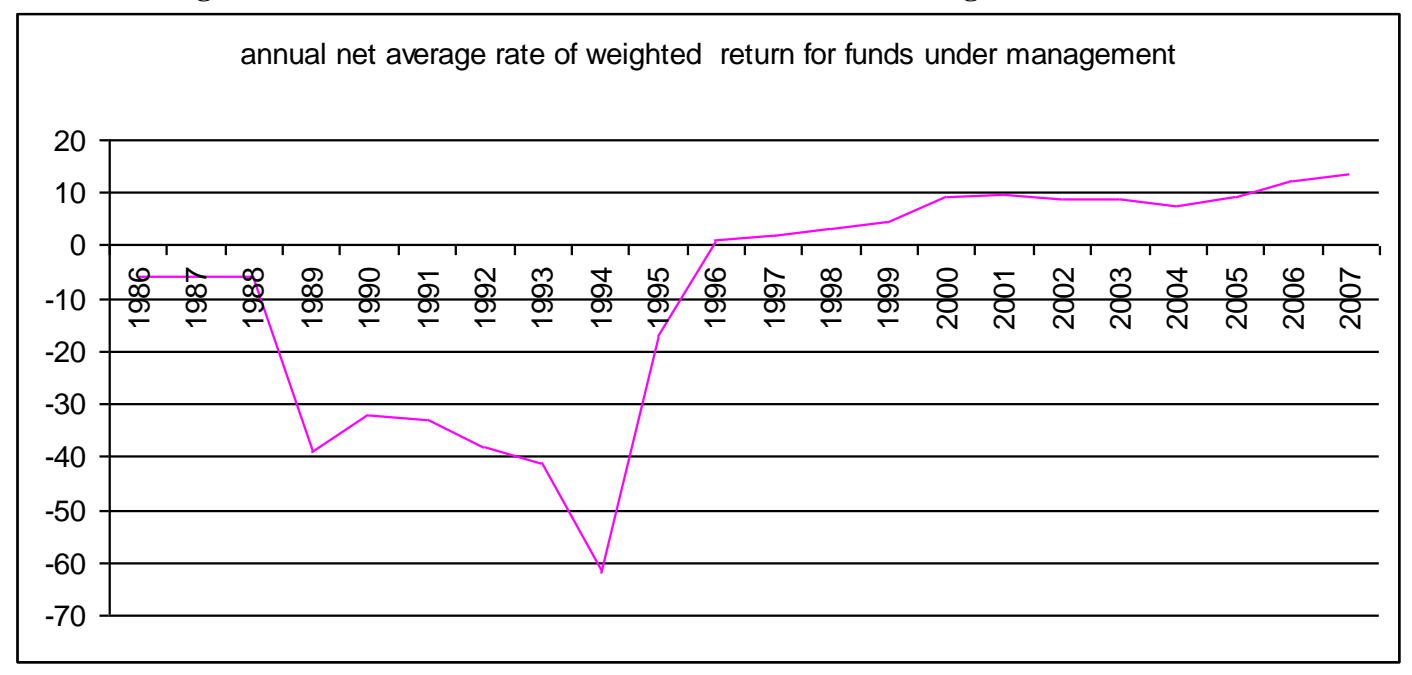

Table10 presents the annual net average rate of weighted return for funds of pension schemes. As indicated, funds of pension schemes recorded a mean rate of return of $2.3 \%$ before the implementation of the RBA Guidelines compared to a cumulative performance of $4.5 \%$ after the implementation of the guidelines. 
Table 10: Annual Net Average Rate of Weighted Investment Returns for Pension Schemes

\begin{tabular}{|l|l|c|c|c|c|}
\hline & & N & Mean & Std. Deviation & Std. Error Mean \\
\hline $\begin{array}{l}\text { Annual net average rate of } \\
\text { weighted investment returns } \\
\text { for pension schemes }\end{array}$ & $\begin{array}{l}\text { before the implementation of RBA } \\
\text { guidelines }\end{array}$ & 11 & 2.2727 & .1 & .03 \\
\cline { 2 - 6 } & $\begin{array}{l}\text { after the implementation of RBA } \\
\text { guidelines }\end{array}$ & 11 & 4.5364 & .2 & .07 \\
\hline
\end{tabular}

As can be seen from the linear trend in Figure 3, average rate of returns for pension schemes were constantly leveled at slightly above $2 \%$ before implementation of the RBA Guidelines. There was however a huge positive shift in performance in 1996, the year following the implementation of the RBA guidelines. The positive shift in investment returns is attributable to short-term governance gains following the introduction of RBA Guidelines.

Figure 3: Annual Average Rate of Investment Returns for Pension Schemes

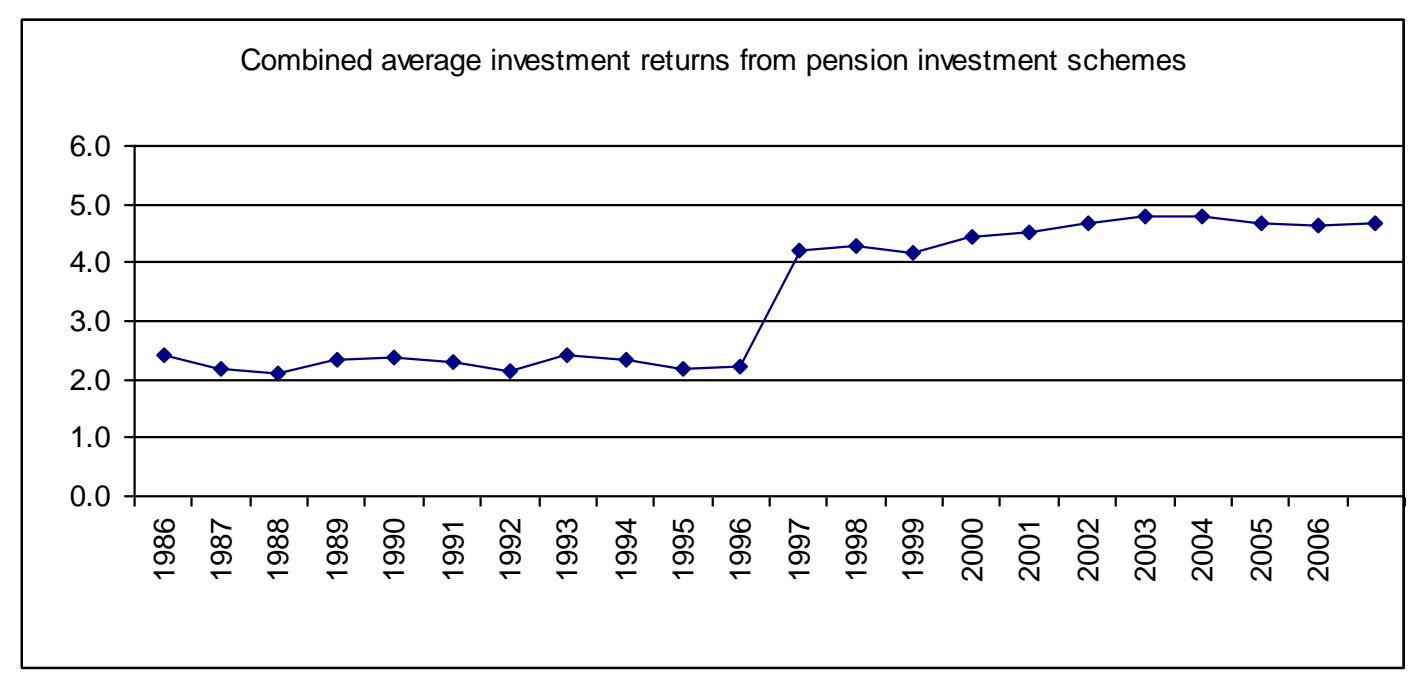

What are the Major Challenges in Operations since the Operationalization and Implementation of the RBA Act of 1997?

Majority of the respondents were of the view that at present, pension provision in the country remains disjointed with occupational and individual schemes falling under the Retirement Benefits Act, while the National Social Security Fund (NSSF) falls under both the NSSF Act and RBA Acts. The Civil Service Scheme falls under the Pensions Act, while there are innumerable legislation covering other areas.

Further, the current policy and legal framework under which Kenya's pension system operates, ignores to large extent coverage of informal sector workers and focuses to some extent on formal sector workers. The fund managers and the RBA indicated that level of pension coverage in Kenya is limited to a mere $15 \%$ of the labor force and thus requires a systemic reform in terms of policy and law in order to widen coverage. The Retirement Benefits Act and the Regulation made there under have therefore not helped in the widening of the coverage of private occupational pension schemes to all the labor force in Kenya.

The study participants pointed to the legal deficiency in the current pension system in the country. There is no law that compels a private employer to provide retirement benefits to its employees. At the same time, there is no law that compels an employee to set aside, or save, any portion of her/his income for future old-age support. An employee's compensation package will include a pension benefit from active employment if both the employer and employee agree that the employer will provide and the employee will accept a portion of her compensation in the form of legally enforceable rights to receive pension payments after retirement. 
Further, the respondents were of the strong view that there exists weak regulatory capacity and that though not all pension schemes have met all the conditions for final registration, none has been taken to court for contravening the RBA Act. In some cases, pension schemes have investment profiles greatly at variance with the prescribed investment guidelines due to gross mismanagement and abuse.

Most of the study participants pointed out that challenges still remain for the RBA to bring some funds in line with the law and fully funded level. Others include post-retirement poverty, low coverage, low contributions rates and the HIV/AIDS epidemic- which had reduced the life expectancy of Kenyans to below the normal retirement age.

\section{CONCLUSIONS AND RECOMMENDATIONS}

\section{Summary of Key Findings}

Fund management market leaders in the country seem to concentrate in few but high value asset portfolio schemes, thus benefiting from economies of scale.

Kenya pension fund investment portfolio is highly diversified in all the vehicles except a large concentration on Kenya government securities, quoted equity and guaranteed funds. Huge proportion funds of pension schemes in the country are therefore invested Kenya Government Securities and quoted equity (shares) and guaranteed funds, a reflection of risk-averseness in pension fund investments and the shift in asset allocation patterns due to the current global crisis. Such conservative investments are impressive in risk locking portfolio losses and but could also reduce the potential of funds to generate retirement incomes in the future. The choice of more conservative asset allocation is also a reflection of the current restrictive and high market-based solvency rules which dictate investment strategies.

The overall weighted returns before the implementation of RBA Guidelines was low (average scale of 1.9) while the weighted returns after the implementation of RBA Guidelines has been high, at an average scale of 3.7. An analysis of the trend however showed that long-run performance has slowed down. Highest growth was realized for mortgage and cash returns as opposed to rights issues and bonus shares. This implies that the implementation of the RBA Guidelines injected governance gains resulting in enhanced the performance of the pension funds in the shortrun but have proved ineffective in the long-run, reflecting fund managers and investment trustees' continued complacence and laxity in complying with the governance mechanisms introduced by the RBA Guidelines. This is a further indication of the current inadequate capacity of the RBA to enforce its guidelines.

The most pertinent concerns for the sector were lack of adequate legal and regulatory framework, the low coverage with marginalization of informal sector, imprudent investments that lead to negative rates of returns on overall investment portfolio. Narrow and restrictive investment guidelines do not promote development of retirement benefits sector, an indication that liberalized investment regimes perform better.

In addition there were pressures arising from shrinking contribution bases and growing beneficiary populations, both of which were caused by contractions in economic activity, the pernicious effect of HIV/AIDS that has lead to an increase in the dependence ratio, a high level of unremitted contributions from the employers to the schemes, inefficient administration and institution weaknesses that increase costs or reduce returns to member's, poor governance and insufficient expertise. It is important to note that though some challenges have been outlined, they however still require further research.

\section{CONCLUSIONS}

It can be concluded from the results that the performance of pension schemes in Kenya, with regard to return on investment, is not sustainable owing low levels of growth against a backdrop of high overall inflation, the after-effects of the global financial and economic crisis which eroded off-shore and Nairobi Stock Market asset values, the inadequate legal and regulatory environment and the incapacity challenges of the industry regulator to monitor and enforce governance, and investment guidelines for pension schemes and fund managers. 
The current prescriptive pension regulations, including quantitative asset restrictions on investment vehicles, were, however, effective in the short run, but have proved ineffective in the long-term. The results can be interpreted to imply that asset regulations imposing quantitative limits on different asset classes reduce the set of otherwise admissible investment policies with consequential effect on return on investments.

\section{RECOMMENDATIONS}

The Regulator needs to implement measures to ensure pension funds are insulated from inflationary and other risks. An effective way is to institute a pension risk insurance fund that will underwrite and compensate such losses as will be prescribed. Further, there is need for a systematic indexation of benefits to inflation.

The RBA needs to enhance its regulatory capacity of the industry in order to ensure compliance among pension schemes and fund managers. An evaluation should be conducted in order to map out areas, roles and departments that should be enhanced. Specifically, the authority needs to strengthen its compliance and enforcement function in order to ensure that it appropriately deals with emerging present and future regulatory challenges. The RBA also needs to move away from proactive supervision of schemes toward a more risk based supervision approach. The primary areas of risk once a scheme is properly set up in compliance with the law are: financial loss of funds; violation of member protection regulations; inefficiencies that increase costs or reduce returns to member's; and poor quality of service to members or beneficiaries Investment regulations should be reviewed to enhance growth of the sector. The investment policy of fund managers should ensure that the retirement benefits are ahead of inflation.

Fund managers should develop good systems to mitigate on the enormous risks they face in their duty as investment managers. Scheme Trustees should be trained in risk management in order to oversee the schemes' investments.

The government should enhance and provide substantial tax incentives to stimulate growth in the industry. The effort by the government to give tax incentives to retirement benefit schemes is commendable; however, the current tax limits on contributions and benefits are too low- contributions to registered retirement benefits schemes are tax deductible from gross income at a maximum of Ksh 20,000 per month.

\section{AUTHOR INFORMATION}

Lucy Jepchoge Rono is a Graduate Assistant at the Department of Accounting and Finance at Moi University, School of Business and Economics. She holds B.Sc Bo Degree (Hons) from Moi University, Master of Business Administration (Entrepreneurship) from Moi University and Master of Business and Management (Finance) from Moi University. Email: jepchoge@yahoo.com

Julius Kibet Bitok, M.B.A.(University of Nairobi) is a Lecturer at the Department of Accounting and Finance, Moi University, Eldoret, Kenya. He has taught in the department for five years. He is also the undergraduate studies coordinator at the School of Business and Economics. He teaches courses in finance and quantitative techniques. He is a doctoral student at Moi University, school of Business and Economics and is in the dissertation phase of his program. Email: hezkibet@yahoo.com

Gordon Newlove Asamoah is a lecturer and a Public Policy Analyst at the Department of Accounting and Finance at Kwame Nkrumah University of Science and Technology School of Business. He holds B.Ed Social Science Degree (Hons) from the University of Cape Coast, Ghana and Msc (Econs) in Public Policy from the University of Hull, UK. Email: gnasamoah.ksb@knust.edu.gh or gasamoahn@yahoo.com

\section{REFERENCES}

1. Ambachtsheer K P et al (1998): Pension Fund Excellence; creating value for Stakeholders. vikas, New Delhi 
2. Andrews E S and Rashid M (1996); The Financing of Pension Systems in Central an Eastern Europe; An overview of Major trends and their Determinants 1990-1993 World Bank Technical Paper No 339, World Bank Washington DC

3. Appleby, R. C. (1994); Modern Business, Macmilan, London

4. Bernheim S C (1998); Financial Education and Information to Participants ;Pensions in the United States, World Bank Washington DC

5. Business Week (2002): The Enron Scandal, Can You Trust Anymore? McGraw-Hill Co Inc Commissioner of Iinsurance (2004) Circular No. CI/01/02 Government of Kenya Printers Nairobi

6. Coomber, K, (2003); Professional pension: specialist investment managers. Deloitte and Touche, New Jersey

7. Dearborn (1999): Principles of Retirement Planning, $3^{\text {rd }}$ Edition Prentice Hall New Jersey.

8. Deloitte and Touche, (2004); Strategic Risk Management, Deloitte and Touche Insight. April 2004 Issue.

9. Emily, S.A.. and Mansoora, R. (1996). The Financing of Pension Systems in Central and Eastern Europe: An Overview of Major Trends and their Determinants 1990-1993, World Bank, Washington DC.

10. Fortune (2004); Investors Guide 2004, Cover Story, Fortune Magazine, Europe Edition, January 2004

11. Gordon C.(2004);Pension Fund Governance; The World Bank, Washington DC

12. Government of Kenya Government (2004): Insurance Act Cap 487 (2004) Government of Kenya Government Printers Nairobi Kenya

13. Grubel, S and Fadner, R (2001); The Interdependence of International Equity Market, Journal of Finance, March 2001 pp 89-94

14. Holzmann, R. and Hinz, R. Old Age Income Support in the $21^{\text {st }}$ Century: An International Perspective on Pension Schemes and Reform World Bank, Washington DC.

15. Holzmann, R. and Palmer, E (2005). Pension Reform: issues and Prospects for Non-Financial Defined Contribution Schemes, World Bank, Washington DC.

16. Kagagi D (2004) - Investment by pension schemes, Professional Management Journal (March 2004)

17. Kiptanui T.(2003); A new Dawn in Retirement Benefits $19^{\text {th }}$ Trustee Training Seminar, April 25 ${ }^{\text {th }} 2003$, Seminar material

18. Kluwer (1996); Handbook on Pensions, Kluwer and Crooner Publishing Limited, London

19. Kothain (1999) Research methods New Delhi

20. Lindermann, D. et al (2000) The Evolution of Pension Systems in Eastern Europe and Central Asia: Opportunities, Constraints, Dillemas and Emerging Practices, World Bank, Washington DC.

21. Machira C (2004) The Role of Pension Trustees Trustee Training Seminar, March $25^{\text {th }} 2004$, Seminar material

22. Marwa S.M. (1992): Actuarial Costing Methods used in Insured Pension Schemes in Kenya, Unpublished MBA Project, University of Nairobi

23. Mghali F (2003); Employee Pension and its Effects: A case of Combrok Limited. Mombasa Unpublished MBA Project, University of Nairobi

24. MicroSave-Africa (2000); Savings in Africa, A Collection of Studies from MicroSave- Africa, UNDP/DFID Initiative

25. Mikula and Setttergrea (1997); Income Related Old Age Pension-Financed Issues WorldBank, Washington $\mathrm{DC}$

26. Mogera D (2006); Kenya Uganda hand over Railways to private firm, Reuters Bristol Rail Branch (0224)

27. Mogera S (1999): Planning for Retirement, (A case of the university of Nairobi staff), Unpublished MBA project, University of Nairobi.

28. Morindat L.N (2005): Impact Assessment of Pension Reform in Kenya. MBA thesis, Moi University Eldoret

29. Mugenda A G, Mugenda O M (1999); Research Methods, Quantitative and Qualitative Approaches, ACTS Press, Nairobi

30. Mugweru T W (2001); Factors affecting the efficiency of the national provident funds in Kenya: A case of National Social Security Fund, Unpublished MBA Thesis, University Of Nairobi

31. Mutuku,M (2007) Investment of Retirement Benefits Funds; Trustee Training. February,2007,Seminar material

32. Mworia N C (2000) The Dawn of Retirement Trustee Training Seminar, 19 November 2000, Seminar material 
33. Myners Report (2001); Role of Trustee in investment of pension Fund, Department for Work and Pension UK

34. Njiru N M (2008); The General Role and Responsibilities of Trustees; RBA Trustee Training Seminar Material $29^{\text {th }}$ February 2008

35. Odundo E (2003); Supervision of a public pension fund experience and challenges in Kenya, second public pensions fund management conference World Bank Washington DC

36. Okemo C B (2000) The Retirement Benefits Act (No 3 of 1997) Kenya Gazette (Supplement No 72; Government of Kenya Printers Nairobi

37. Otieno B. (2003) : Challenges Facing Management of Pension Funds in the Investment Industry in Kenya, Unpublished MBA Thesis, Moi University

38. Placios D, Iglesias S (2000) Managing Public Pension Reserves Part 1:Evidence from International Experience, Social Protection Discussion Paper No 0003, World Bank, Washington DC

39. RBA Annual Report (2003), Chairman's Statement, Annual Report

40. $\quad$ RBA NEWS (2007); Survey Reveal Lack of Private Sector Pensioners, Quarterly News

41. Saunders M., Lewis P., Thornhill A.,(2003); Research Methods for Business Students Rotolito Lumbards, Italy

42. Sluchynkyy O, Rutkowski M and Linderman D (2005); The Evolution of Pension Systems in Eastern Europe and Central Asia: Opportunities,Constraints, Dilemmas and Emerging Practices, World Bank Washington DC

43. Srinivas P S, Yermon J ,(1999);Investment Regulations Compromise Pension Fund Performance; Evidence from Latin America and Caribbean Studies, World Bank Washington DC

44. Tausch Arno (2007): World Bank Pension Reforms and Development Patterns in the world system

45. The Economic Research (2001); Almanac of China's economy; Eurasia Press New York

46. Thialer R H and Sustein C R (2003); The Paternalistic Liberalism; American Economic Review

47. Thietart R A et al (1999); Doing Management Research; A comprehensive Guide. SAGE Publications, London

48. Thomas, S (2000) Equity investment in pension asset management in India.

49. Vermo, J (2008); Governance and Investment of Public Pension Reserve Fund in Selected countries; Financial Market Trend, World Bank, Washington DC

50. Wachira W (2008); The Role of Trustees in Investment of Retirement Benefits Scheme Assets; RBA Trustee Training Seminar Material $29^{\text {th }}$ February 2008

51. Wachira W (2008); The Role of Trustees in Investment of Retirement Benefits Scheme Assets; RBA Trustee Training Seminar Material

52. www.eoc.org.uk

53. www.pensioworld.co.ke

www.rba.go.ke

www.weforum.org. 